\title{
ANALIZA WYKORZYSTANIA MIEJSC NOCLEGOWYCH W PRZEDSIĘBIORSTWACH HOTELARSKICH W ŚWIETLE BADAŃ
}

\begin{abstract}
W artykule przedstawiono wyniki badań dotyczące wykorzystania miejsc noclegowych w hotelach Nadwiślańskiej Agencji Turystycznej (NAT). Badania zostały przeprowadzone za lata 2014-2016. Analizie zostało objętych osiem hoteli należących do NAT. Spośród wszystkich obiektów objętych badaniem i po uwzględnieniu całkowitej liczby udzielonych noclegów okazało się, że najwyższy wskaźnik obłożenia miejsc noclegowych we wszystkich badanych okresach, tj. od 2014 do 2016 roku miał hotel „Górnik”. Najniższą wartość tego wskaźnika odnotowano w przypadku hotelu „Neptun” w 2014 roku oraz w hotelu „Za Wydmą” w roku 2015 i 2016. W przypadku hoteli: „Górnik”, „Jawor” i „Neptun” w okresie badawczym zaobserwowano tendencję wzrostową, zaś w pozostałych obiektach odnotowano wahania wzrostu bądź spadku analizowanego zjawiska. Dokonując analizy skumulowanej liczby osobonoclegów udzielonych w hotelach NAT w 2016 roku z wykorzystaniem indeksów jednopodstawowych ustalono poziom najwyższego oraz najniższego spadku badanego zjawiska w stosunku do przyjętego okresu bazowego. Uwzględniając ogół korzystających, najwyższy spadek liczby udzielonych noclegów w odniesieniu do miesiąca lipca, który przyjęto za podstawę wyznaczenia indeksów odnotowano w grudniu $79,21 \%$, zaś najniższy w sierpniu $6,02 \%$. Na podstawie przeprowadzonych badań można stwierdzić, iż poziom wykorzystania miejsc noclegowych w większości badanych obiektów jest zadawalający.
\end{abstract}

\footnotetext{
${ }^{1}$ Dr Wojciech Chudy, Katedra Zarządzania, Wydział Zarządzania Sportem i Turystyką, Akademia Wychowania Fizycznego im. Jerzego Kukuczki w Katowicach, ul. Mikołowska 72A, 40-065 Katowice; tel. 322075329; e-mail: w.chudy@awf.katowice.pl (autor korespondencyjny).

Wojciech Chudy, PhD, Faculty of Management of Sport and Tourism, The Jerzy Kukuczka Academy of Physical Education in Katowice, Mikołowska 72A, 40-065 Katowice; mobile: 0048322075329; e-mail: w.chudy@awf.katowice.pl (corresponding author).

2 Prof. dr hab. Romuald Szopa, Katedra Zarządzania, Wydział Zarządzania Sportem i Turystyką, Akademia Wychowania Fizycznego im. Jerzego Kukuczki w Katowicach, ul. Mikołowska 72A, 40-065 Katowice; tel. 322075325; e-mail: r.szopa@awf.katowice.pl.

Romuald Szopa, Prof., DSc, PhD, Faculty of Management of Sport and Tourism, The Jerzy Kukuczka Academy of Physical Education in Katowice, Mikołowska 72A, 40-065 Katowice; mobile: 0048322075329; e-mail: r.szopa@awf.katowice.pl.

${ }^{3}$ Dr Michał Kucharski, Katedra Zarządzania Sportem i Turystyką, Wydział Zarządzania Sportem i Turystyką, Akademia Wychowania Fizycznego im. Jerzego Kukuczki w Katowicach, ul. Mikołowska 72A, 40-065 Katowice; tel. 322075362; e-mail: m.kucharski@ awf.katowice.pl.

Michał Kucharski, PhD, Faculty of Management of Sport and Tourism, The Jerzy Kukuczka Academy of Physical Education in Katowice, Mikołowska 72A, 40-065 Katowice; mobile: 0048322075329; e-mail: m.kucharski@awf.katowice.pl.
} 
Wartości wskaźnika obłożenia w hotelach należących do Nadwiślańskiej Agencji Turystycznej nie odbiegały od wartości odnotowanych w analogicznym okresie w Polsce przez Główny Urząd Statystyczny, a w niektórych przypadkach znacząco te wartości przewyższał.

Słowa kluczowe: przedsiębiorstwo hotelarskie, mierniki w hotelarstwie, osobonocleg.

\section{WSTĘP}

Świadczenie usług hotelarskich oraz kreowanie turystycznej bazy noclegowej poprzez funkcjonowanie różnorodnych przedsiębiorstw hotelarskich wraz z ofertą usługową to istotne zadania współczesnego hotelarstwa. Przemysł hotelowy jest istotną częścią sektora turystycznego. Turystyka, jej intensywny rozwój oraz rosnące i dywersyfikujące się potrzeby turystów wpływają na rozbudowę bazy noclegowej, aktywizację produkcji gastronomicznej i wzrost ilościowy różnorodnych usług realizowanych w przedsiębiorstwach hotelarskich ${ }^{4}$.

Celem artykułu jest prezentacja wykorzystania miejsc noclegowych w hotelach Nadwiślańskiej Agencji Turystycznej (NAT). Zbadanych zostanie osiem obiektów, dla których przeprowadzona zostanie analiza dotyczącą liczby udzielonych osobonoclegów, w której wykorzystano takie wskaźniki dynamiki ${ }^{5}$ zjawisk jak: indeksy łańcuchowe, indeksy jednopodstawowe. Objęte badaniem hotele NAT zlokalizowane są na północy i południu Polski. Przyjęty do analizy szereg czasowy obejmuje lata od roku 2014 do roku 2016. W analizie uwzględniono zarówno liczbę osobonoclegów udzielonych w hotelach NAT klientom polskim, jak i zagranicznym.

\section{WYBRANE MIERNIKI STOSOWANE W PRZEDSIĘBIORSTWACH HOTELARSKICH}

Zgodnie z przyjętą przez G. Konsewicza i J. Grabowskiego definicją, hotelarstwo ${ }^{6}$ to społecznie zorganizowana działalność usługowa, polegająca na udzielaniu gościnności przyjezdnym. Zaspokaja potrzebę wypoczynku, pożywienia, noclegu, rozrywek kulturalnych, łączności z otoczeniem ${ }^{7}$.

Z powyższego wynika fakt, iż jednym z kluczowych zadań zarządzania w hotelarstwie stają się strategiczne i operacyjne działania przedsiębiorstwa związane z analizą aktualnych i przyszłych możliwości świadczenia usług noclegowych.

Hotelarstwo bazuje na szerokiej gamie świadczonych usług ${ }^{8}$, noszących nazwę pakietów (ang. hotel package). Istnieją hotele niezależne, będące najczęściej obiektami małymi

${ }^{4}$ A. Panasiuk, D. Szostak (red.), Hotelarstwo. Ustugi, eksploatacja, zarzadzanie, Warszawa 2008, s. 7.

${ }_{5}$ Patrz szerzej: A. Bielecka, Statystyka dla menedżerów: teoria i praktyka, Warszawa 2017, s. 301-341; A. Maksimowicz-Ajchel, Funkcjonowanie przedsiębiorstwa. Wybrane zagadnienia statystyki, Warszawa 2004, s. 98-106.

${ }^{6}$ Patrz szerzej: M. Sidorkiewicz, Podstawowa terminologia zwiazana z hotelarstwem, [w:] Hotelarstwo. Ustugi, eksploatacja, zarzadzanie, red. A. Panasiuk, D. Szostak, Warszawa 2008, s. 22.

7 J. Czerwiński, Podstawy turystyki, Wrocław-Poznań 2011, s. 231-235.

8 Patrz szerzej: A. Mazurkiewicz, M. Sidorkiewicz, A. Tokarz-Kocik, Oferta hotelarska schronisk młodzieżowych w Polsce jako element produktu turystyki szkolnej. Ujęcie teoretyczno-empiryczne, „Ekonomiczne Problemy Turystyki”, nr 1 (37), red. B. Meyer, Szczecin 2017, s. 49-59. 
(do 30 pokoi), stanowiące przedsiębiorstwa rodzinne, oparte na autonomii prawnej, finansowej i gospodarczej. Inną kategorię stanowią hotele zrzeszone w dobrowolnych łańcuchach hoteli ${ }^{9}$.

Ustawa z dnia 29 sierpnia 1997 r. o usługach turystycznych, definiuje hotel jako obiekt posiadający, co najmniej 10 pokoi, w tym większość miejsc w pokojach jednoosobowych i dwuosobowych, świadczący szeroki zakres usług związanych z pobytem klientów ${ }^{10}$.

Przedsiębiorstwa hotelarskie, które potrafią szybko zrozumieć i zaspokajać potrzeby klientów, osiągają większe zyski niż te, które nie rozumieją i nie zaspokajają swoich klientów. Zapewnienie wysokiej jakości usług i poprawa satysfakcji klientów są powszechnie uznawane za podstawowe czynniki wpływające na wyniki firm z branży hotelarsko-turystycznej ${ }^{11}$.

Do ogólnie pożądanych i oczekiwanych kierunków rozwoju hotelarstwa w Polsce zalicza się: przyrost bazy noclegowej, lepsze rozmieszczenie obiektów na terenie kraju, modernizację i dostosowanie standardu hoteli do potrzeb gości, i inne ${ }^{12}$.

Wśród mierników ${ }^{13}$ charakteryzujących hotelarstwo można wskazać dwie grupy: mierniki wielkości bazy usługowej hotelarstwa, charakteryzujące wielkość użytkową obiektu hotelarskiego lub jego części oraz mierniki usług hotelarskich, charakteryzujące rozmiary świadczonych usług w wielkościach bezwzględnych lub w stosunku do rozmiarów bazy usługowej ${ }^{14}$.

Liczba udzielonych noclegów i liczba tzw. osobodni, czyli faktycznie liczba sprzedanych jednostek usługowych, to miary działalności obiektu hotelarskiego. Mierniki działalności obiektów hotelarskich wykorzystują, jako podstawę liczbę udzielonych noclegów. Pojęcia: osobodzień, osobonocleg, a nawet łóżkodzień bywają utożsamiane i definiowane, jako wielkość wytworzonej w ciągu doby usługi przypadającej na jednego gościa ${ }^{15}$.

Miernikiem mającym również zastosowanie w hotelarstwie jest nominalna liczba noclegów, tj. liczba miejsc, które można wynajać w danym okresie. Liczba ta jest równa iloczynowi liczby stałych miejsc noclegowych i liczby dni działalności hotelu w danym okresie. Dzieląc liczbę noclegów udzielonych w danym okresie przez nominalną liczbę noclegów w badanym okresie, otrzymujemy wskaźnik wykorzystania miejsc. Wskaźnik ${ }^{16}$

9 J. Czerwiński, Podstawy..., s. 231-235.

${ }^{10}$ Ustawa z dnia 29 sierpnia 1997 r. o usługach turystycznych ( Dz.U. z 1997 r., nr 133, poz. 884 ze zm.).

11 J. Gozaly, Consumer analysis for increasing occupancy rates of tourism hotel, "Industrial Engineering and Management Systems", 2017, 16 (1), s. 103-108.

12 J. Borzyszkowski, S. Dudziak, Analiza oferty specjalnych pakietów pobytowych i ich wykorzystania w obiekcie hotelarskim na przyktadzie Royal Park Hotel \& Spa w Mielnie [w:] Ustugi w Polsce 2012. Ustugi publiczne - ustugi komercyjne, red. J. Buko, Zeszyty Naukowe Uniwersytetu Szczecińskiego nr 723, „Ekonomiczne Problemy Usług” nr 96, 2012 s. 193-204.

${ }_{13}$ Patrz szerzej: D. Milewski, Mierniki charakteryzujace hotelarstwo [w:] Hotelarstwo. Ustugi, eksploatacja, zarzadzanie, red. A. Panasiuk, D. Szostak, Warszawa 2008, s. 96-101.

${ }_{14}$ M. Turkowski, Marketing ustug hotelarskich, Warszawa 2010, s. 22.

${ }^{15} \mathrm{https}: / / \mathrm{www}$.google.pl/url?sa=t\&rct=j\&q=\&esrc=s\&source=web\&cd=5\&ved=0ahUKEwi_9Mrpo c3WAhXhApoKHbISBtsQFgg8MAQ\&url=http\%3A\%2F\%2Fonte.wsg.byd.pl\%2Fmoodle\%2Ffil e.php\%2F1\%2Fpdf\%2Fpodstawy_hotelarstwa\%2FM01_3_PH_tresc.pdf\&usg=AOvVaw3I0CgM Lj3M6xsEf7xNGned, dokument dostępny online (dostęp: 30.09.2017 r.).

${ }^{16}$ Patrz szerzej: Abdul Sada Mutlag Raheem Al Saleem, Noorya Flayyih Mzaiel Al-Juboori, Factors Affecting Hotels Occupancy Rate (An Empirical Study on Some Hotels in Amman), Interdis- 
wykorzystania miejsc pozwala porównać osiągnięcie sukcesu rynkowego przez hotele różnej wielkości czy rodzaju. Natomiast stosunek liczby udzielonych noclegów do liczby gości zamieszkałych w hotelu, który określa liczbę noclegów przypadających średnio na jednego gościa hotelowego to tzw. wskaźnik długości pobytu ${ }^{17}$.

\section{NADWIŚLAŃSKA AGENCJA TURYSTYCZNA (NAT)}

Nadwiślańska Agencja Turystyczna powstała w 1996 roku. Od ponad 18 lat w 20 obiektach wczasowych stara się zapewnić gościom wszystko, co najlepsze w wypoczynku w Polsce ${ }^{18}$. Misja NAT brzmi: ,Stwarzamy warunki do zaspokojenia potrzeb wypoczynkowych i rekreacyjnych rosnącej liczby Klientów z kraju i zagranicy, poprzez szeroką i zróżnicowaną ofertę produktów, dążenie do podwyższania standardu ośrodków oraz przyjazną obsługę" ${ }^{19}$.

NAT to zespół ludzi pracujących z pasją i ogromnym zaangażowaniem starających się udowodnić, że wypoczynek w Polsce może być udany. Rezultaty tej pracy potwierdza ok. pół miliona osób będących stałymi klientami. Nadwiślańska Agencja Turystyczna to przede wszystkim wyjątkowe lokalizacje, najpiękniejsze polskie plaże, czyste jeziora, góry, coraz lepsza, jakość obiektów, ulepszanie standardów obsługi, kategoryzacje, polska, domowa, zdrowa i smaczna kuchnia, profesjonalne usługi profilaktyczno-lecznicze i sanatoryjne, standard dla każdego i w przystępnej cenie ${ }^{20}$.

Większość obiektów należących do NAT posiada między innymi ${ }^{21}$ :

- place zabaw dla dzieci,

- boiska sportowe,

- zewnętrzne siłownie,

- wypożyczalnie rowerów i kijów do Nordic Walking,

- sale konferencyjne,

- kawiarnie,

- wifi.

Ponadto Nadwiślańska Agencja Turystyczna jest właścicielem stacji narciarskiej „Cieńków” w Wiśle. Stacja narciarska „Cieńków” to nowoczesna kolej linowa (kanapy 4-osobowe), a także: wyciągi talerzykowe, strefa dla dzieci, trasy ratrakowane, naśnieżane oraz oświetlone, wypożyczalnie sprzętu, szkoły i przedszkola narciarskie oraz punkty gastronomiczne ${ }^{22}$.

\section{CHARAKTERYSTYKA HOTELI NAT}

Nadwiślańska Agencja Turystyczna wśród swoich obiektów hotelarskich posiada osiem hoteli $(* * *)$ zlokalizowanych na północy oraz południu Polski. Spośród ośmiu

ciplinary Journal of Contemporary Research in Business, October 2013, Vol. 5, No. 6, s. $142-159$.

${ }_{17}$ M. Turkowski, Marketing..., s. 25-26.

${ }^{18} \mathrm{http}: / /$ www.nat.pl/firma-nat/informacje-o-spolce (dostęp: 2.10.2017 r.).

19 Tamże.

20 Tamże.

${ }^{21}$ Tamże.

22 Tamże. 
hoteli, pięć z nich zlokalizowanych jest w północnej części Polski (w Kołobrzegu, Sarbinowie, Krynicy Morskiej, Świnoujściu i Jarosławcu), trzy pozostałe hotele znajdują się w Wiśle, Ustroniu i Krynicy-Zdroju - na południu kraju. Ich charakterystykę przedstawiono poniżej:

1. Hotel „Górnik” w Kołobrzegu znajduje się w nadmorskim parku, w odległości $250 \mathrm{~m}$ od morza, niedaleko Starówki w Kołobrzegu. Hotel jest obiektem sanatoryjnym, oferującym pakiety zabiegów dla gości ${ }^{23}$.

2. Hotel ,Jagiellonka” zlokalizowany jest w ścisłym centrum Krynicy-Zdroju. Obiekt ten jest doskonałym punktem wypadowym do zwiedzania okolicy uzdrowiska. Nieopodal hotelu znajduje się pijalnia wód „Jan” i stacja kolejki szynowej na Górę Parkową. Goście mogą korzystać z kompleksowej bazy zabiegowej znajdującej się na terenie hotelu. Obiekt polecany jest gościom indywidualnym na wczasy, wczasy z zabiegami oraz na pobyty grupowe, imprezy integracyjne i szkolenia ${ }^{24}$.

3. Hotel „Jawor” w Sarbinowie to komfortowy obiekt, znajdujący się $100 \mathrm{~m}$ od plaży, z basenami: krytym i otwartym oraz gabinetami odnowy biologicznej. Hotel polecany jest dla rodzin $\mathrm{z}$ dziećmi ${ }^{25}$.

4. Hotel „Neptun” w Krynicy Morskiej umiejscowiony na dużym, zalesionym terenie, $100 \mathrm{~m}$ od morza. Na terenie znajdują się 4 pawilony wczasowe, po generalnym remoncie o wysokim standardzie oraz nowoczesne domki campingowe. Hotel polecany dla gości indywidualnych na wczasy i pobyty weekendowe oraz na pobyty grupowe, zwłaszcza dla dzieci i młodzieży w okresie wakacji i dla seniorów po sezonie $^{26}$.

5. Hotel „Ogrodzisko” w Wiśle położony jest nad potokiem Malinka, na malowniczym stoku Cieńkowa, w dzielnicy Malinka. Stanowi on doskonałe miejsce wypoczynku dla całej rodziny. Hotel posiada gabinet odnowy biologicznej. Bezpośrednio przy obiekcie znajduje się kolej linowa „Cieńków”27.

6. Hotel „Rybniczanka” w Świnoujściu zlokalizowany w malowniczej części dzielnicy nadmorskiej, $100 \mathrm{~m}$ od Promenady i $150 \mathrm{~m}$ od plaży. Hotel oferuje szeroką gamę zabiegów leczniczych. $\mathrm{Na}$ infrastrukturę hotelu składają się między innymi: kompleks basenowy, sauny, jacuzzi, sala gimnastyczna z mini siłownią. Ośrodek polecany dla gości indywidualnych, jak i dla grup zorganizowanych ${ }^{28}$.

7. Hotel „Za Wydmą" w Jarosławcu to nowoczesny i komfortowy obiekt o wysokim standardzie. Obiekt doskonale zlokalizowany, w centrum Jarosławca, w odległość $450 \mathrm{~m}$ od morza. Hotel do dyspozycji gości oddaje 80 pokoi, restaurację oraz profesjonalnie przygotowaną bazę zabiegową ${ }^{29}$.

8. Hotel „Ziemowit” w Ustroniu-Zawodziu - położony jest na Skarpie Wiślanej w uzdrowiskowej części Ustronia. Obiekt znajduje się niedaleko centrum. Hotel

\footnotetext{
${ }^{23} \mathrm{http}: / /$ www.nat.pl/nasze-obiekty/hotel-gornik-w-kolobrzegu (dostęp: 25.09.2017 r.).

${ }^{24} \mathrm{http}: / /$ www.nat.pl/nasze-obiekty/hotel-dwl-jagiellonka-krynica-zdroj (dostęp: 25.09.2017 r.).

${ }^{25} \mathrm{http}: / /$ www.nat.pl/nasze-obiekty/hotel-jawor-w-sarbinowie (dostęp: 25.09.2017 r.).

${ }^{26} \mathrm{http}: / /$ www.nat.pl/nasze-obiekty/hotel-neptun-w-krynicy-morskiej (dostęp: 25.09.2017 r.).

${ }^{27} \mathrm{http}: / /$ www.nat.pl/nasze-obiekty/hotel-ogrodzisko-w-wisle (dostęp: 25.09.2017 r.).

${ }^{28} \mathrm{http}$ ://www.nat.pl/nasze-obiekty/hotel-rybniczanka-w-swinoujsciu (dostęp: 25.09.2017 r.).

${ }^{29} \mathrm{http}: / /$ www.nat.pl/nasze-obiekty/ow-za-wydma-w-jaroslawcu (dostęp: 25.09.2017 r.).
} 
posiada dobrze rozwiniętą infrastrukturę sportowo-rekreacyjną, w postaci między innymi: boiska do siatkówki, sali do ćwiczeń, bazy zabiegowej i innych ${ }^{30}$.

Przedstawione powyżej obiekty hotelarskie należące do NAT ze względu na swoje położenie, bogatą ofertę, dostępne wyposażenie sportowo-rekreacyjne i inne stwarzają szerokie możliwości dla korzystających na udany odpoczynek i relaks podczas pobytów.

\section{ANALIZA WYKORZYSTANIA MIEJSC NOCLEGOWYCH W HOTELACH NAT}

Analizą w zakresie wykorzystania miejsc noclegowych (osobonoclegów) zostało objętych osiem w/w hoteli (***) należących do NAT. Dane do poniższej analizy uzyskano z NAT w ramach realizacji projektu badawczego. Badania przeprowadzono z uwzględnieniem podziału korzystających z usług analizowanych obiektów na klientów: polskich i zagranicznych w latach 2014-2016. Liczbę osobonoclegów udzielonych klientom polskim przedstawiono w tabeli 1.

Tabela 1. Liczba osobonoclegów w latach 2014-2016 - klienci polscy

\begin{tabular}{|l|c|c|c|c|c|c|}
\hline \multirow{2}{*}{ Hotel } & \multirow{2}{*}{$\mathbf{2 0 1 4}$} & \multirow{2}{*}{$\mathbf{2 0 1 5}$} & \multirow{2}{*}{$\mathbf{2 0 1 6}$} & \multicolumn{3}{c|}{$\begin{array}{c}\text { Zmiana w \% } \\
\text { (dot. indeks lańcuchowy) }\end{array}$} \\
\cline { 5 - 7 } & & & & $\mathbf{2 0 1 4}$ & $\mathbf{2 0 1 5}$ & $\mathbf{2 0 1 6}$ \\
\hline „Górnik” & 17295 & 16755 & 18607 & - & $-3,00$ & 11,00 \\
\hline „Jagiellonka” & 24951 & 23226 & 25337 & - & $-7,00$ & 9,00 \\
\hline „Jawor” & 52132 & 54565 & 60706 & - & 5,00 & 11,00 \\
\hline „Neptun” & 40413 & 41987 & 53125 & - & 4,00 & 27,00 \\
\hline „Ogrodzisko” & 15082 & 15667 & 15113 & - & 4,00 & $-4,00$ \\
\hline „Rybniczanka” & 7352 & 8663 & 10255 & - & 18,00 & 18,00 \\
\hline „Za Wydmą" & 24107 & 17931 & 18842 & - & $-26,00$ & 5,00 \\
\hline „Ziemowit” & 30088 & 26191 & 26004 & - & $-13,00$ & $-1,00$ \\
\hline
\end{tabular}

Źródło: opracowanie własne na podstawie badań własnych.

Najwyższą liczbę osobonoclegów udzielonych klientom polskim w obiektach NAT odnotowano w hotelu „Jawor”, zaś najniższą w hotelu „Rybniczanka” (tabela 1, rys. 1). Następnie wyznaczono indeksy łańcuchowe, dla których punktem odniesienia dla każdego momentu czasowego jest wartość zjawiska w okresie bezpośrednio go poprzedzającym. Pozwoliło to ustalić okresy, w których miał miejsce wzrost lub spadek analizowanego zjawiska. Najwyższy dodatni przyrost liczby udzielonych osobonoclegów odnotowano w hotelu „Neptun” (27\%) w 2016 roku w stosunku do roku poprzedniego, największy spadek wartości liczby udzielonych noclegów miał miejsce w przypadku hotelu „Za Wydmą” (26\%) w roku 2015 w stosunku do roku 2014 (tabela 1).

\footnotetext{
${ }^{30} \mathrm{http}: / /$ www.nat.pl/nasze-obiekty/hotel-ziemowit-w-ustroniu (dostęp: 25.09.2017 r.).
} 


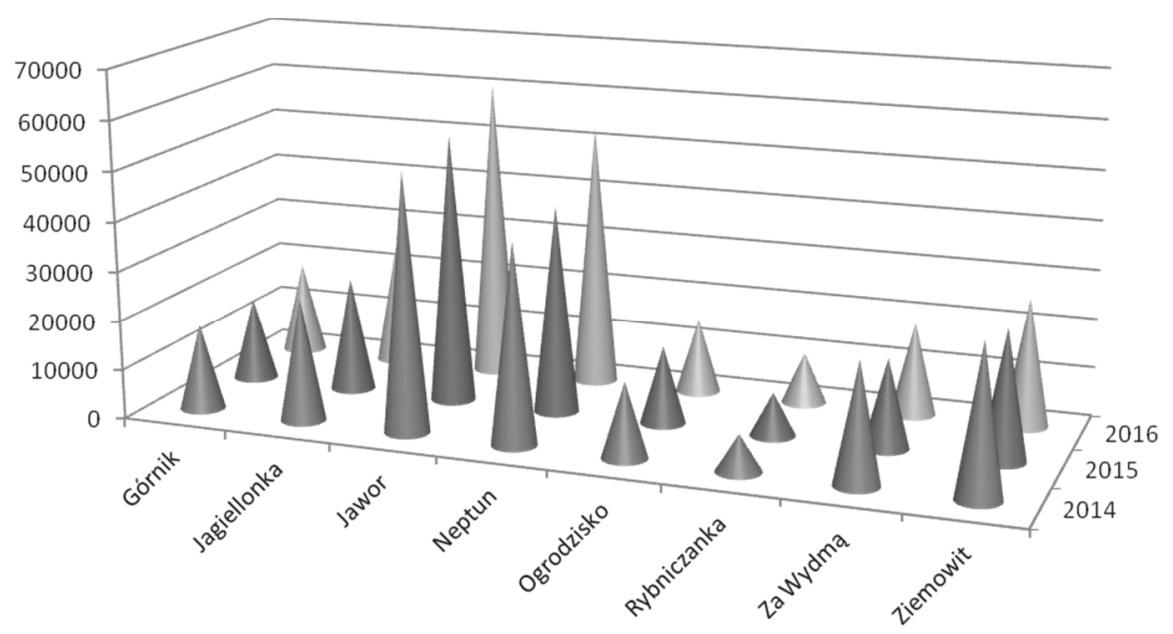

Rys. 1. Liczba osobonoclegów udzielonych polskim klientom w hotelach NAT w latach 2014-2016 Źródło: opracowanie na podstawie badań własnych.

Analizując osobonoclegi udzielone klientom zagranicznym, najwyższą ich liczbę odnotowano w hotelu „Rybniczanka”, zaś najniższą w hotelu „Za wydmą” (tabela 2, rys. 2).

Tabela 2. Liczba osobonoclegów w latach 2014-2016 - klienci zagraniczni

\begin{tabular}{|l|c|c|c|c|c|c|}
\hline \multirow{2}{*}{ Hotel } & \multirow{2}{*}{$\mathbf{2 0 1 4}$} & \multirow{2}{*}{$\mathbf{2 0 1 5}$} & \multirow{2}{*}{$\mathbf{2 0 1 6}$} & \multicolumn{3}{c|}{$\begin{array}{c}\text { Zmiana w \% } \\
\text { (dot. indeks lańcuchowy) }\end{array}$} \\
\cline { 5 - 7 } & & & & $\mathbf{2 0 1 4}$ & $\mathbf{2 0 1 5}$ & $\mathbf{2 0 1 6}$ \\
\hline „Górnik” & 24157 & 26063 & 25624 & - & 8,00 & $-2,00$ \\
\hline „Jagiellonka” & 412 & 312 & 304 & - & $-24,00$ & $-3,00$ \\
\hline „Jawor” & 656 & 1220 & 640 & - & 86,00 & $-48,00$ \\
\hline „Neptun” & 264 & 361 & 337 & - & 37,00 & $-7,00$ \\
\hline „Ogrodzisko” & 807 & 981 & 951 & - & 22,00 & $-3,00$ \\
\hline „Rybniczanka” & 50336 & 45497 & 51447 & - & $-10,00$ & 13,00 \\
\hline ,Za Wydmą" & 74 & 189 & 118 & - & 155,00 & $-38,00$ \\
\hline ,Ziemowit” & 713 & 934 & 612 & - & 31,00 & $-34,00$ \\
\hline
\end{tabular}

Źródło: opracowanie własne na podstawie badań własnych.

Wyznaczone indeksy łańcuchowe wskazały, iż w przypadku hotelu „Za Wydmą” $\mathrm{w}$ analizowanym szeregu czasowym odnotowano zarówno najwyższy wzrost (w roku $2015-155 \%$ ), jak i spadek (w roku 2016 - 38\%) liczby udzielonych noclegów (tabela 2 , rys. 2). 


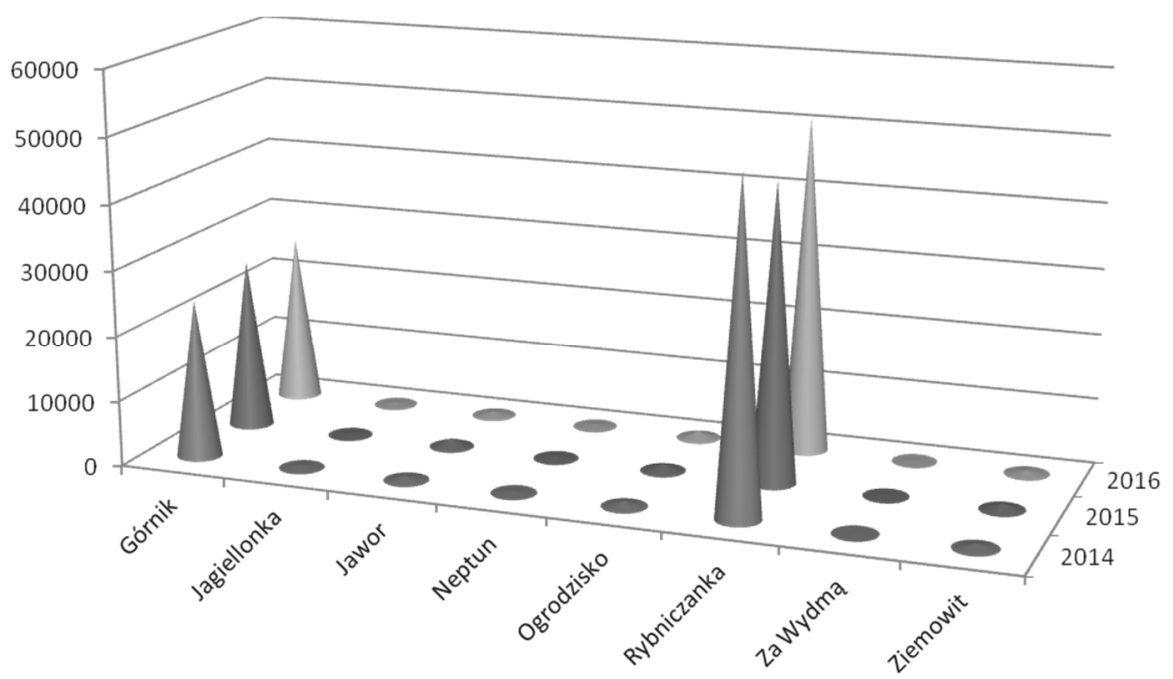

Rys. 2. Liczba osobonoclegów udzielonych zagranicznym klientom w hotelach NAT w latach 2014-2016

Źródło: opracowanie na podstawie badań własnych.

W dalszej części analizy zgromadzono dane dotyczące liczby osobonoclegów udzielonych klientom polskim i zagranicznym w hotelach NAT oraz wyrażony procentowo stopień wykorzystania tych miejsc i indeksy łańcuchowe dla analizowanego szeregu czasowego (tabela 3, rys. 3).

Tabela 3. Liczba osobonoclegów oraz wskaźnik obłożenia miejsc noclegowych w latach 2014-2016 - klienci polscy i zagraniczni

\begin{tabular}{|l|c|c|c|c|c|c|c|c|c|}
\hline \multirow{2}{*}{ Hotel } & \multicolumn{2}{|c|}{2014} & \multicolumn{2}{c|}{$\mathbf{2 0 1 5}$} & \multicolumn{2}{c|}{2016} & \multicolumn{3}{c|}{$\begin{array}{c}\text { Zmiana w \% } \\
\text { (dot. indeks lańcuchowy) }\end{array}$} \\
\cline { 2 - 11 } & Liczba & \% & Liczba & \% & Liczba & \% & $\mathbf{2 0 1 4}$ & $\mathbf{2 0 1 5}$ & $\mathbf{2 0 1 6}$ \\
\hline „Górnik” & 41452 & 69,67 & 42818 & 71,97 & 44231 & 74,14 & - & 3,00 & 3,00 \\
\hline „Jagiellonka” & 25363 & 46,95 & 23538 & 43,57 & 25641 & 47,34 & - & $-7,00$ & 9,00 \\
\hline „Jawor” & 52788 & 46,80 & 55785 & 49,46 & 61346 & 54,24 & - & 6,00 & 10,00 \\
\hline „Neptun” & 40677 & 27,05 & 42348 & 28,16 & 53462 & 35,45 & - & 4,00 & 26,00 \\
\hline „Ogrodzisk” & 15889 & 32,73 & 16648 & 34,29 & 16064 & 33,00 & - & 5,00 & $-4,00$ \\
\hline „Rybniczanka” & 57688 & 68,72 & 54160 & 64,51 & 61702 & 73,30 & - & $-6,00$ & 14,00 \\
\hline „Za Wydmą” & 24181 & 37,22 & 18120 & 27,89 & 18960 & 29,10 & - & $-25,00$ & 5,00 \\
\hline „Ziemowit” & 30801 & 55,52 & 27125 & 48,89 & 26616 & 47,84 & - & $-12,00$ & $-2,00$ \\
\hline
\end{tabular}

Źródło: opracowanie własne na podstawie badań własnych. 
Najwyższym stopniem wykorzystania miejsc noclegowych charakteryzuje się hotel „Górnik” - odpowiednio w roku 2014 - 69,67\%, 2015 r. - 71,97\% i 2016 r. - 74,14\%. Natomiast najniższy stopień wykorzystania miejsc noclegowych odnotowano w $2014 \mathrm{r}$. w hotelu „Neptun” - 27,05\% oraz w 2015 r. i 2016 r. w hotelu „Za Wydmą” - 27,89\% i $29,10 \%$ (tabela 3 ).

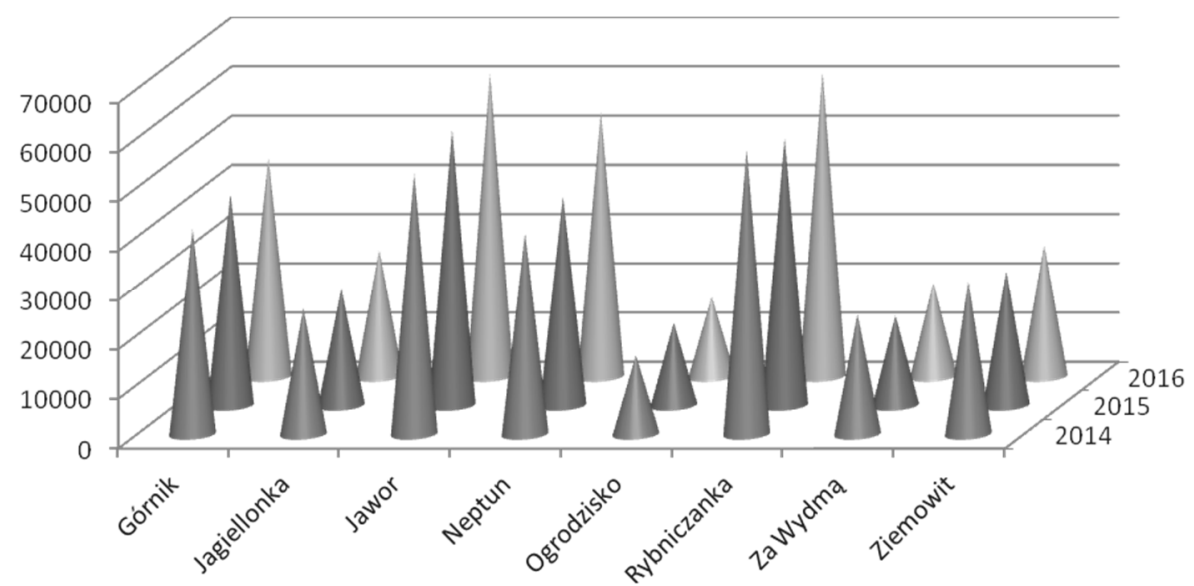

Rys. 3. Liczba osobonoclegów udzielonych polskim i zagranicznym klientom w hotelach NAT w latach 2014-2016

Źródło: opracowanie na podstawie badań własnych.

Analizując indeksy łańcuchowe w przypadku hoteli: „Górnik”, „Jawor” i „Neptun” w latach 2014-2016 odnotowano zauważalną tendencję wzrostową, zaś w pozostałych przypadkach występowały wahania charakteryzujące się wzrostem lub spadkiem badanego zjawiska (tabela 3).

Ostatni etap analizy dotyczył skumulowanej liczby osobonoclegów w hotelach NAT w poszczególnych miesiącach w 2016 r. (tabela 4).

Wyniki uzyskane na tym etapie badania wykazały, iż najwięcej osobonoclegów udzielanych klientom polskim ma miejsce w miesiącu lipcu i sierpniu, klientom zagranicznym w miesiącach: maj, wrzesień, październik, zaś najwyższą liczbę osobonoclegów obejmującą wszystkich klientów zaobserwowano w lipcu - 52820 (tabela 4, rys. 4).

Z uwagi na zaobserwowane duże różnice zachodzące w liczbie udzielanych noclegów w poszczególnych miesiącach, na tym etapie analizy wyznaczono indeksy jednopodstawowe, dla których punktem odniesienia jest stała wartość (w tym przypadku wyznaczono miesiąc bazowy w każdej analizowanej grupie) stanowiąca podstawę obliczeń dla wszystkich analizowanych okresów czasowych. Mając na uwadze powyższe za podstawę wyznaczenia indeksów jednopodstawowych przyjęto te miesiące, w których odnotowano najwyższą liczbę udzielonych noclegów. W przypadku liczby udzielonych noclegów: klientom polskim był to miesiąc lipiec, klientom zagranicznym - wrzesień oraz uwzględniając wszystkie udzielone noclegi - lipiec. Analizując indeksy ustalono, iż najwyższy 


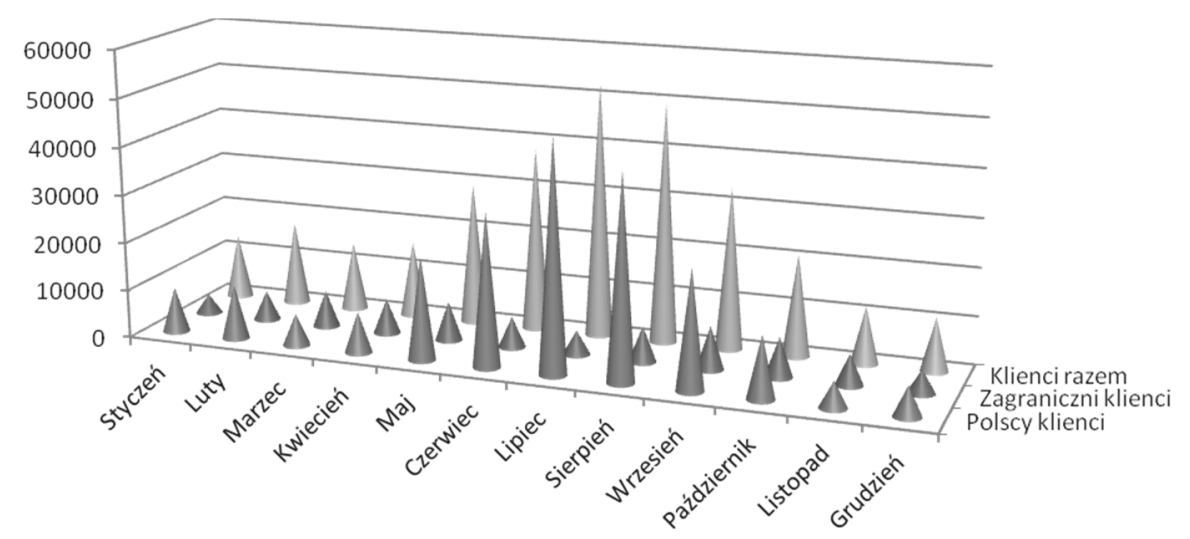

Rys. 4. Skumulowana liczba osobonoclegów udzielonych w hotelach NAT w 2016 r. według miesięcy

Źródło: opracowanie na podstawie badań własnych.

spadek liczby udzielonych noclegów klientom polskim w stosunku do przyjętego miesiąca bazowego miał miejsce w listopadzie $(88,73 \%)$, najniższy zaś w sierpniu $(11,81 \%)$. Dla klientów zagranicznych otrzymano odpowiednio: najwyższy spadek w styczniu $(54,85 \%)$ oraz najniższy w październiku (7,63\%), (tabela 4, rys. 5).

Tabela 4. Skumulowana liczba osobonoclegów udzielonych w hotelach NAT w 2016 r.

\begin{tabular}{|c|c|c|c|c|c|c|}
\hline \multirow{3}{*}{ Miesiąc } & \multicolumn{6}{|c|}{$\begin{array}{c}\text { Hotele NAT: „Górnik”, ,,Jagiellonka”, ,Jawor”, „,Neptun”, ,,Ogrodzisko”, } \\
\text {,Rybniczanka”, ,ZZa Wydmą”, ,Ziemowit”, }\end{array}$} \\
\hline & \multirow{2}{*}{$\begin{array}{l}\text { Polscy } \\
\text { klienci }\end{array}$} & \multirow{2}{*}{$\begin{array}{c}\text { Zagran. } \\
\text { klienci }\end{array}$} & \multirow{2}{*}{$\begin{array}{c}\text { Klienci } \\
\text { razem }\end{array}$} & \multicolumn{3}{|c|}{$\begin{array}{c}\text { Zmiana w \% } \\
\text { (dot. indeks jednopodstawowy) }\end{array}$} \\
\hline & & & & $\begin{array}{l}\text { Polscy } \\
\text { klienci }\end{array}$ & $\begin{array}{l}\text { Zagran. } \\
\text { klienci }\end{array}$ & $\begin{array}{c}\text { Klienci } \\
\text { razem }\end{array}$ \\
\hline Styczeń & 9327 & 4027 & 13354 & $-80,52$ & $-54,85$ & $-74,72$ \\
\hline Luty & 11337 & 6068 & 17405 & $-76,32$ & $-31,97$ & $-67,05$ \\
\hline Marzec & 6639 & 7597 & 14236 & $-86,13$ & $-14,83$ & $-73,05$ \\
\hline Kwiecień & 8472 & 7204 & 15676 & $-82,30$ & $-19,24$ & $-70,32$ \\
\hline Maj & 21314 & 8098 & 29412 & $-55,48$ & $-9,22$ & $-44,32$ \\
\hline Czerwiec & 31736 & 6359 & 38095 & $-33,71$ & $-28,71$ & $-27,88$ \\
\hline Lipiec & $47877 *$ & 4943 & $52820 *$ & 100,00 & $-44,59$ & 100,00 \\
\hline Sierpień & 42223 & 7418 & 49641 & $-11,81$ & $-16,84$ & $-6,02$ \\
\hline Wrzesień & 24542 & $8920 *$ & 33462 & $-48,74$ & 100,00 & $-36,65$ \\
\hline Październik & 12929 & 8239 & 21168 & $-73,00$ & $-7,63$ & $-59,92$ \\
\hline Listopad & 5397 & 6373 & 11770 & $-88,73$ & $-28,55$ & $-77,72$ \\
\hline Grudzień & 6196 & 4787 & 10983 & $-87,06$ & $\begin{array}{l}-46,33 \\
\end{array}$ & $-79,21$ \\
\hline
\end{tabular}

* - oznacza miesiąc bazowy stanowiący podstawę obliczeń dla analizowanych okresów czasowych Źródło: opracowanie własne na podstawie badań własnych. 
Natomiast uwzględniając ogół korzystających z noclegów w odniesieniu do miesiąca lipca, który przyjęto za podstawę wyznaczenia indeksów, odnotowano również najwyższy oraz najniższy spadek liczby udzielonych noclegów w miesiącu grudniu i sierpniu, który wyniósł odpowiednio: 79,21\% i 6,02\% (tabela 4, rys. 5).

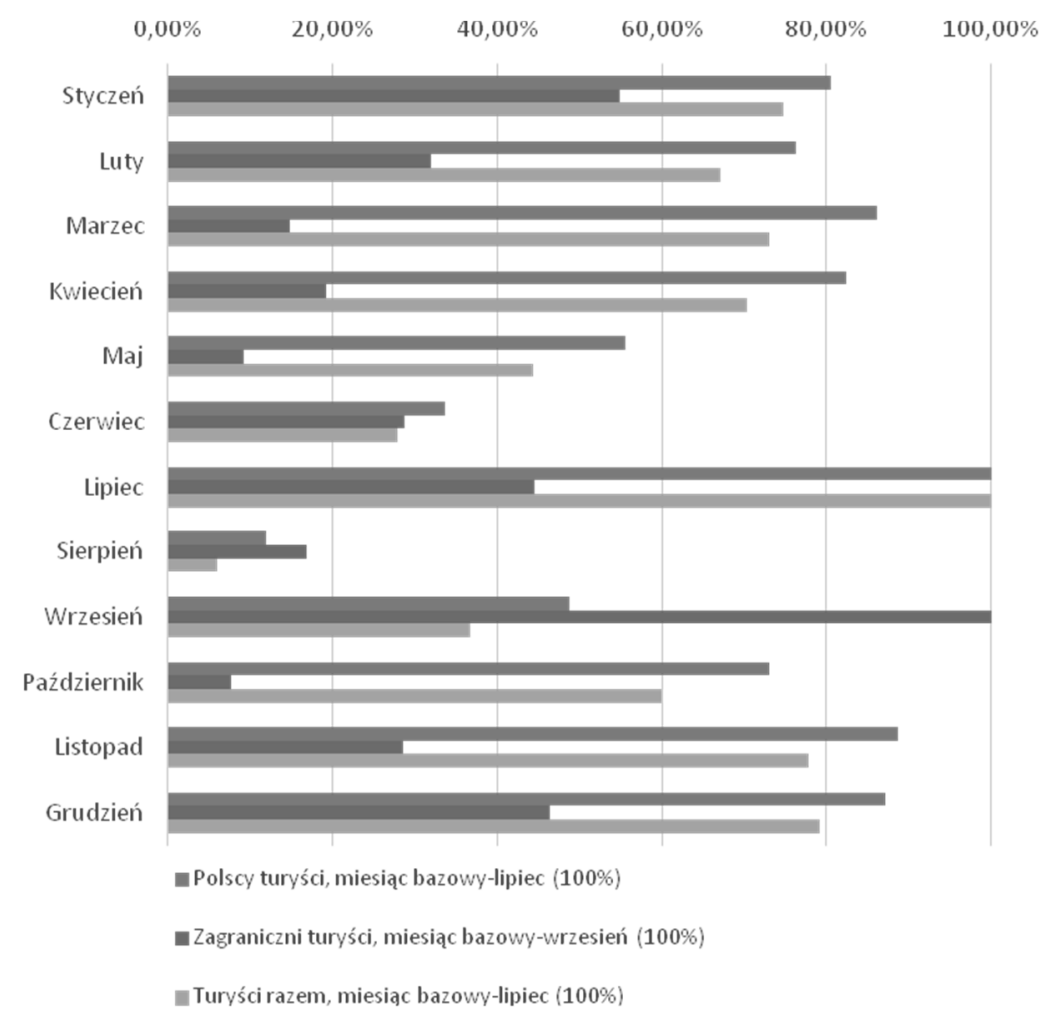

Rys. 5. Indeksy jednopodstawowe skumulowanej liczby osobonoclegów udzielonych w hotelach NAT w $2016 \mathrm{r}$.

Źródło: opracowanie na podstawie badań własnych.

\section{PODSUMOWANIE}

Powyższa analiza dotyczyła wykorzystania miejsc noclegowych w hotelach należących do NAT w latach 2014-2016. Zbadano osiem obiektów, dla których przeprowadzono analizę dotyczącą liczby udzielonych osobonoclegów, w której wykorzystano takie wskaźniki dynamiki jak: indeksy łańcuchowe oraz indeksy jednopodstawowe.

Spośród wszystkich obiektów objętych badaniem i uwzględnieniu całkowitej liczby udzielonych noclegów okazało się, że najwyższy wskaźnik obłożenia miejsc noclegowych we wszystkich badanych okresach, tj. od 2014 r. do 2016 r. miał hotel „Górnik”. Najniższą wartość tego wskaźnika odnotowano w przypadku hotelu „Neptun” w 2014 r. oraz w hotelu „Za Wydmą” w roku 2015 i w roku 2016. W przypadku hoteli: „Górnik”, 
„Jawor” i „Neptun” w okresie badawczym zaobserwowano tendencję wzrostową, zaś w pozostałych obiektach odnotowano wahania wzrostu bądź spadku analizowanego zjawiska.

Dokonując analizy skumulowanej liczby osobonoclegów udzielonych w hotelach NAT w 2016 r. z wykorzystaniem indeksów jednopodstawowych ustalono poziom najwyższego oraz najniższego spadku badanego zjawiska w stosunku do przyjętego okresu bazowego. Uwzględniając ogół korzystających, najwyższy spadek liczby udzielonych noclegów w odniesieniu do miesiąca lipca, który przyjęto za podstawę wyznaczenia indeksów odnotowano w grudniu 79,21\%, zaś najniższy w sierpniu 6,02\%.

Odnosząc się do danych dotyczących wskaźnika wykorzystania miejsc noclegowych w polskich hotelach, który według GUS ${ }^{31}$ w roku: 2014, 2015 i 2016 wynosił odpowiednio: $34,2 \%, 36,5 \%$ i $38,5 \%$, można stwierdzić, iż poziom wykorzystania miejsc noclegowych w badanych obiektach jest zadowalający. Spośród wszystkich badanych obiektów jedynie w przypadku hoteli „Neptun”, „Ogrodzisko” i „Za Wydmą” odnotowano niższą wartość wskaźnik obłożenia w stosunku do wskaźnika uzyskanego dla Polski. W pozostałych przypadkach wartości wskaźnika obłożenia w hotelach NAT w sposób znaczący przewyższały wartości odnotowane przez GUS w analogicznym okresie w Polsce.

\section{Literatura}

1. Abdul Sada Mutlag Raheem Al Saleem, Noorya Flayyih Mzaiel Al-Juboori, Factors Affecting Hotels Occupancy Rate (An Empirical Study on Some Hotels in Amman), Interdisciplinary Journal of Contemporary Research in Business, October, Vol. 5, No. 6, 2013.

2. Bielecka A., Statystyka dla menedżerów: teoria i praktyka, Wydawnictwo Nieoczywisteimprint GAB Media, Warszawa 2017.

3. Borzyszkowski J., Dudziak S., Analiza oferty specjalnych pakietów pobytowych i ich wykorzystania $w$ obiekcie hotelarskim na przykładzie Royal Park Hotel \& Spa w Mielnie, „Ekonomiczne Problemy Usług”, red. J. Buko, nr 96, Wydawnictwo Naukowe Uniwersytetu Szczecińskiego, Szczecin 2012.

4. Czerwiński J., Podstawy turystyki, Wydawnictwo Wyższej Szkoły Bankowej w Poznaniu, Wrocław-Poznań 2011.

5. Gozaly J., Consumer analysis for increasing occupancy rates of tourism hotel, "Industrial Engineering and Management Systems", 16 (1), 2017.

6. http://www.nat.pl/firma-nat/informacje-o-spolce (dostęp: 2.10.2017 r.).

7. http://www.nat.pl/nasze-obiekty/hotel-dwl-jagiellonka-krynica-zdroj (dostęp: 25.09.2017 r.).

8. http://www.nat.pl/nasze-obiekty/hotel-gornik-w-kolobrzegu (dostęp: 25.09.2017 r.).

9. http://www.nat.pl/nasze-obiekty/hotel-jawor-w-sarbinowie (dostęp: 25.09.2017 r.).

10. http://www.nat.pl/nasze-obiekty/hotel-neptun-w-krynicy-morskiej (dostęp: 25.09.2017 r.).

11. http://www.nat.pl/nasze-obiekty/hotel-ogrodzisko-w-wisle (dostęp: 25.09.2017 r.).

12. http://www.nat.pl/nasze-obiekty/hotel-rybniczanka-w-swinoujsciu (dostęp: 25.09.2017 r.).

\footnotetext{
${ }^{31}$ Stopień wykorzystania miejsc noclegowych w hotelach (***) dla Polski według Głównego Urzędu Statystycznego za lata: 2014, 2015, 2015 wynosił odpowiednio: 34,2\%, 36,5\% i 38,5\%, https://bdl.stat.gov.pl/BDL/start (dostęp: 6.10.2017 r.).
} 
13. http://www.nat.pl/nasze-obiekty/hotel-ziemowit-w-ustroniu (dostęp: 25.09 .2017 r.).

14. http://www.nat.pl/nasze-obiekty/ow-za-wydma-w-jaroslawcu (dostęp: 25.09.2017 r.).

15. https://bdl.stat.gov.pl/BDL/start (dostęp: 6.10.2017 r.).

16. https://www.google.pl/url?sa=t\&rct=j\&q=\&esrc $=$ s\&source=web\&cd=5\&ved=0ahUKEwi _9Mrpoc3WAhXhApoKHbISBtsQFgg8MAQ\&url=http\%3A\%2F\%2Fonte.wsg.byd.pl\%2 Fmoodle\%2Ffile.php\%2F1\%2Fpdf\%2Fpodstawy_hotelarstwa\%2FM01_3_PH_tresc. pdf\&usg=AOvVaw3I0CgMLj3M6xsEf7xNGned (dostęp: 30.09.2017 r.).

17. Maksimowicz-Ajchel A., Funkcjonowanie przedsiębiorstwa. Wybrane zagadnienia statystyki, WSIP, Warszawa 2004.

18. Mazurkiewicz A., Sidorkiewicz M., Tokarz-Kocik A., Oferta hotelarska schronisk młodzieżowych w Polsce jako element produktu turystyki szkolnej. Ujęcie teoretyczno-empiryczne, „Ekonomiczne Problemy Turystyki”, red. B. Meyer, nr 1 (37), Wydawnictwo Naukowe Uniwersytetu Szczecińskiego, Szczecin 2017.

19. Milewski D., Mierniki charakteryzujące hotelarstwo [w:] Hotelarstwo. Ustugi, eksploatacja, zarzadzanie, red. A. Panasiuk, D. Szostak, Wydawnictwo Naukowe PWN, Warszawa 2008.

20. Panasiuk A., Szostak D (red.), Hotelarstwo. Ustugi, eksploatacja, zarzadzanie, Wydawnictwo Naukowe PWN, Warszawa 2008.

21. Sidorkiewicz M., Podstawowa terminologia zwiazana $z$ hotelarstwem [w:] Hotelarstwo. Usługi, eksploatacja, zarządzanie, red. A. Panasiuk, D. Szostak, Wydawnictwo Naukowe PWN Warszawa 2008.

22. Turkowski M., Marketing ustug hotelarskich, Polskie Wydawnictwo Ekonomiczne, Warszawa 2010.

23. Ustawa z dnia 29 sierpnia 1997 r. o usługach turystycznych (tekst jedn. Dz.U. z 1997 r., nNr 133. poz. 884).

\section{RESEARCH ANALYSIS OF THE ACCOMMODATION USING AT HOTELS}

The article presents the results of research in the accommodation using at the hotels of the Nadwiślańska Agencja Turystyczna (NAT). The research was carried out for the years 2014-2016. The analysis covers eight hotels which belong to NAT. From among all the facilities covered by the study and taking into account the total number of overnight stays, it turned out that the highest occupancy rate in all analyzed periods, from 2014 to 2016 year, was held by the "Górnik" hotel. The lowest value of this indicator was recorded in the "Neptun" hotel in 2014 and in the "Za Wydmą" hotel in 2015 and 2016. In the hotels: "Górnik", "Jawor" and "Neptun", an upward trend was observed during the research period; in other objects there were fluctuations in the increase or decrease of the analyzed phenomenon. To analyse the cumulated numbers of accommodations, delivered in NAT hotels in 2016, which the single-base indices, the level of the highest and the lowest decrease in the examined phenomenon was established. Considering all users, the highest decrease in the number of overnight stays in July (which was adopted as the basis for determining the indices) was recorded in December 79,21\%, and the lowest in August - 6,02\%. On the basis of the research, it can be concluded that the level of accommodation using in most of the 
examined facilities is satisfactory. The values of the occupancy index in hotels of the NAT did not differ from the values recorded in the same period in Poland by the Central Statistical Office, and in some cases significantly exceeded those values.

Keywords: hotel business, quantitative measure in hotel industry, individual-accommodation.

DOI: $10.7862 /$ rz.2018.mmr.2

Tekst złożono $w$ redakcji: grudzień 2017 r.

Przyjęto do druku: kwiecień 2018 r. 